\title{
Do Economic Reforms Spur Bancarisation Rate in the CEMAC Region? Empirical Analysis
}

\author{
Gérard Tchouassi ${ }^{1}$ \\ ${ }^{1}$ Department of Economics, Faculty of Economics and Management, University of Yaoundé II, Yaoundé, \\ Cameroon
}

Correspondence: Gérard Tchouassi, Department of Economics, Faculty of Economic and Management, University of Yaoundé II, Po Box 1365 Yaoundé, Cameroon. Tel: 237-6-9992-0998. E-mail: tchouassigerard@yahoo.fr

Received: January 12, 2016

Accepted: February 2, 2016

Online Published: March 25, 2016

doi:10.5539/ijef.v8n4p123

URL: http://dx.doi.org/10.5539/ijef.v8n4p123

\begin{abstract}
The aim of this paper is to empirically analyze the effect of the economic reforms on the bancarisation rate in the Central Africa Economic and Monetary Community (CEMAC). Data of six countries from the sub-region from 2001 to 2011 was used in a generalized method of moment (GMM) modeling framework. The following results are obtained: Financial liberalization has facilitated the opening of bank accounts. The opening of bank accounts demand is an increasing function of Gross Domestic Product per capita. The literacy rate contributes to the improvement of financial and banking services. Public and private infrastructures promote decentralization and delocalization of the banking network to smaller cities and rural areas. Institutional reforms work best for increasing the bancarisation rate where financial and banking activities are weak. So, the economic policy to be implemented is to continue the economic and financial reforms and ameliorate the quality of the institutions in the CEMAC region.
\end{abstract}

Keywords: Bancarisation rate, economic reforms, financial liberalization, unbanked, GMM

\section{Introduction}

How many people in Africa have bank accounts? Why, for what and how do they utilize? Although, Banks are important financial intermediaries' operating not only in developed countries but also in developing countries where they can help populations to save, borrow and invest. Are the issues of bancarisation in Africa still based on the economic reforms undertaken in the monetary and financial system? Economic reforms processes and growing in the bancarisation rate is a contemporary economic and financial phenomenon debatable in economic, finance and public spheres. Analyzing the mechanisms and the conditions of financing economy has grown considerably since the work of Gurley and Shaw (1960), which demonstrates the importance of finance in the process of economic growth. After them many other authors like Mathieson (1980), Sachs and Warner (1995), Iyigun and Rodrik (2004) have considered that economic and financial reforms have turned into a more determining dimension of the productive development particularly for African countries. At the same time, this has being closely link to financial liberalization. Numerous contributions on this theme can be decomposed in two main facets: the first one is the tradition of normative liberalism based on the efficiency of the market against the state intervention; the second one is more specific to the development sphere. The seminal work of McKinnon (1973) and Shaw (1973) is based on financial repression and on the financial deepening.

Financial repression refers to the concept that a set of government rules, laws, and other non-market limitations inhibit the financial intermediaries of an economy from performing at their complete competence. The economic policies that cause financial repression in Central African countries consist of: interest rate ceilings, liquidity percentage requirements, high bank reserve necessities, and assets controls. Limitations on market access into the monetary zone, credit ceilings or restrictions on guidelines of credit distribution, and supervision ownership or authority of banks are also the characteristics of financial repression. Financial deepening is referring to the improved provision of financial services with a wider option of services geared to all levels of the institutions. In addition, it refers to the macro impacts of financial deepening on the larger economy. Generally, financial deepening captures an improved in the percentage of currency supply to gross domestic product or some price index. It is associated to liquid currency. The additional liquid currency is offered in a financial system, the 
supplementary opportunities subsist for sustained development. But the current liquidity of the African financial cooperation region (CFA zone) is debatable nowadays. Financial deepening may also be defined as an increase in the dimension of the financial system and in its function and frequency in the economy. From a monetary policy viewpoint, the emerging diversification of firms' and households' portfolios is mainly related, as they are more and more affected by the developments in financial markets.

Economic and financial reforms now underway in the CEMAC countries (Cameroun, Central Africa Republic, Chad, Congo Republic, Equatorial Guinea, and Gabon) include as their planned objective the combination of the domestic financial system with the international economy. Integration signifies not simply augmented market-based trade and financial flows, however also institutional coordination with regard to financial policy, trade policy, legal codes, tax systems, ownership patterns, and other regulatory arrangements (Sachs \& Warner, 1995). Economic reforms indicate a country necessary structural adjustment to external economic and financial events. These reforms incorporate the function of country's expenditure to the level parallel to their incomes and thereby reducing fiscal deficits. This has necessitated continuing reduction in import and increase in export. These adjustments also insist on market transform in order to make economy elastic. Economic and financial reforms were experimental in a various guidelines: institutional reforms which planning goal is to build up a helpful, practiced, truthful and clear unrestricted service dedicated to the protection of independent principles. The anticorruption procedures, which the principal goal is to fight against dishonesty and fraud, are very important in the reform. The anticorruption principles administered in the CEMAC countries are intended at reforming law-enforcement and judicial systems, as well as the fiscal, administrative and public service sectors. Important payroll raises for public servants employed in the ministries were carried out within a short time-frame in order to improve combat economic crime, dishonesty, corruption and fraud. Liberal economic reform is one of the main objectives of the economic policy of the CEMAC countries. It consists of the promotion of the development of free enterprise and private entrepreneurship by creating a helpful business climate. Economic and financial reforms are intended at ensuring economic development based on economic and financial liberalization, development of the private sector and extension of financial and banking services.

The Table 1 presents the bancarisation rate and the use of financial services by adults in percentage of 31 African countries from 2005 to 2011. Formally conceived as the percentage of the inhabitants with access to monetary and banking services, bancarisation rate is a high-quality tool used to capture the development of the financial sector and common shorthand for the manner we describe how inclusive a financial system is. Various institutions in Central African countries persevere that they are trailblazers in boosting financial and banking inclusiveness, and point to their development policies as facts. Economic and finance theories propose that sustainable higher estimated development and revisit on assets of the financial sector should be backed by a balance of growth in client base and up/cross-sell of current and new products to existing clients. The level of a country's bancarisation is generally a function of its level of economic development. More developed a country is, the higher the level of banking penetration is high and vice versa. Thus France, Germany and the United States for example, have a bancarisation rate over than $90 \%$, while Yemen, the Central African Republic and Niger have bancarisation rate less than $10 \%$ rate in 2007 . Why this differential in the level of bancarisation rate? Indeed, Schumpeter (1912) has already established the relationship concerning the financial sector and the economic growth through technological innovation.

Table 1. Bancarisation rate of 31 African countries (2005-2011)

\begin{tabular}{|c|c|c|c|c|c|c|c|c|c|c|c|}
\hline $\mathrm{AC}$ & South Africa & Morocco & Namibia & Botswana & Zambia & Togo & Rwanda & Ghana & Kenya & Zimbabwe & Senegal \\
\hline $\mathrm{BR}$ & 80 & 64 & 55 & 54 & 33 & 22 & 20 & 20 & 20 & 20 & 19 \\
\hline UF/A & 46 & 39 & 28 & 47 & 15 & 28 & 23 & 16 & 10 & 34 & 2 \\
\hline $\mathrm{AC}$ & Tanzania & Gabon & Nigeria & Côte d'Ivoire & Mali & Burkina Faso & Cameroon & Djibouti & Congo & Burundi & Mauritania \\
\hline BR & 15 & 15 & 15 & 10 & 10 & 10 & 9 & 8 & 7 & 6 & 5 \\
\hline UF/A & 29 & 39 & 15 & 25 & 22 & 26 & 24 & - & 27 & 17 & 16 \\
\hline $\mathrm{AC}$ & Ethiopia & Benin & Niger & GuineaBissau & Mozambica & $\mathrm{RDC}$ & RCA & Chad & Angola & & \\
\hline $\mathrm{BR}$ & 5 & 4 & 4 & 3 & 3 & 1 & 1 & 1 & 1 & & \\
\hline UF/A & 14 & 32 & 31 & - & 12 & - & 19 & - & 25 & & \\
\hline
\end{tabular}

Note. $\mathrm{AC}=$ African countries; $\mathrm{BR}=$ bancarisation rate in \%; UF/A = Use of financial by adults in \%.

Sources: Author's calculation from www.financialaccess.org

Financial liberalization that took place in the CEMAC region in the 1980s and 1990s was element of the common progress toward giving financial markets a bigger function in growth. It was also a consequence to 
numerous factors explicit to business named: the expenses, corruption, and inefficiencies related with using finance as a tool of state-led development; a desire for more financial resources; citizens' demands for better finance and lower implicit taxes and subsidies; and the pressures exerted on repressed financial systems by better international trade and larger communications.

What are the major obstacles to well-organized financial markets in many Central African countries? First, an inadequate regulatory institution which makes for a greatly concentrated banking sector, very low intermediation rates, and inefficient collateral registry systems that further impede businesses and individuals' access to credit. Second, a banking sector that fails to exercise its role of intermediation due to very high interest rate spreads which make credit expensive. Furthermore, deposits are weakly remunerated. Third, an underdeveloped capital markets that stay contracted and illiquid, thereby restraining access to long-term finance and hindering countries' capacities for local debt financing. And last, a lack of innovative financial tool, notably those geared towards small and medium enterprises, which represent a greater part of the businesses in Africa but remain too often restricted to the unofficial sector due to insufficient financial services.

This paper is based on the theories of financial development, financial deepening and financial liberalization. The literature related on the association between financial development and growth is vast. It dates back to Schumpeter (1912), Gurley and Shaw (1960), McKinnon (1973), Shaw (1973), Fry (1982) and, King and Levine (1993). The aim of this article is to empirically analyze the effect of the economic reforms on the bancarisation rate in the Central Africa Economic and Monetary Community. The paper addresses the successive research questions: is the association between economic and economic reforms and bancarisation rate positive or negative? What is the effect of economic and financial reforms on the bancarisation rate? Do these reforms help to bank the unbanked? To answer these questions the generalized method of moment (GMM) is used. This article analyses the first careful empirical estimates of the impact of the economic and financial reforms on the bancarisation rate in Central Africa Economic and Monetary Community (CEMAC) countries. The content of this paper is as follow: Section 2 reviews the related literature; section 3 presents the methodology: variables selection, econometric model and data source. Section 4 presents and discusses the empirical results; and the last section concludes.

\section{Literature Review}

A number of studies have examining the effect of stock market liberalization on market integration (Errunza \& al., 1992; Buckberg, 1995; Bekaert, 1995; Bekaert \& Harvey, 1995). Nevertheless, none of these studies approximate the assessment effect of stock market liberalization (Stiglitz, 2000) and specifically the bancarisation rate in developing countries.

In the literature, McKinnon (1973) and Shaw (1973) argue that the abolition of financial repression and the liberalization of the financial system are essential for the development of economic growth. The same idea was defended by Kapur (1976), Mathieson (1980), Fry (1995) and Gablis (1997). Contrary to the view of McKinnon (1973) and Shaw (1973); Buffie (1984), Taylor (1983) and Van Wijnbergen (1983) have developed a complementary suggestion. According to them, the financial development decreases with real credit supply and prevents the growth of the economy. According to Buffie (1984), if we allow direct intervention in markets, financial liberalization is a risky venture. The other point of view supported by Patrick (1966) shows that financial development is very crucial for economic growth, but the relationship evolves. During the growth process, the offer was a key driver of the development of the financial sector will be smaller and will be replaced by the application according to Patrick (1966). The financial repression that prevailed in developing and transition countries in the 1970s and 1980s reflected a mix of state-led development. The financial system was treated as an instrument of the treasury: governments allocated credit at below market interest rates, used monetary policy instruments and state-guaranteed external borrowing to ensure supplies of credit for themselves and public sector firms, and directed part of the resources that were left to sectors they favored. Eboue (1990) analyses the macroeconomic effect of the financial repression in the developing countries.

What about the efficacy of reforms (Iyigun \& Rodrik, 2004)? In theory, the arguments for economic and financial reforms towards liberalization appear uncontroversial because based on exacting assumptions. Economic and financial globalization has the potential to raise economic growth and lower consumption volatility. Measuring financial and banking liberalization, Demirgüç-Kunt and Detragiache (1998) suggests that crises tend to erupt when the macroeconomic environment is fragile, particularly when growth is low and inflation is high. Also, high real interest rates are visibly connected with universal banking sector tribulations, and there is some facts that weakness to balance of payments crises has played a function. Countries with an clear deposit insurance system were particularly at risk, as were countries with weak law enforcement. Kaminsky 
and Schmukler (2003) analyzes the chronology of bank liberalization taking into account regulations on deposit interest rates, lending interest rates, distribution of credit, foreign currency deposits and distinguishes the level of openness: repressed, moderately liberalized, and completely liberalized.

Financial deepening is a multi-faceted process that involves the interaction of a number of markets (primary, secondary and retail), instruments (deposits, loans, foreign exchange, bonds and debt securities), and stakeholders (banks, contractual savings institutions, companies). It can be seen as a process in which institutions and financial markets: facilitate goods and services exchange (payment services for example); mobilize and pool savings of a large number of investors; acquire and process information about the companies and the potential investment projects and therefore allocating public savings to the most productive uses; follow investments and exert corporate governance; and diversify and reduce liquidity risk and inter-temporal risk (Levine, 2005; King \& Levine, 1993). In other words, financial deepening can be understood as a process by which the range of products and players widens, deadlines extend and services play a role in risk coverage and diversification.

Kiyotaki and Moore (2004) extend a representation of financial deepening, found on the difference between restricted bilateral obligation and limited multilateral commitment. The authors investigate the impacts of material changes in financial depth on investment and output; on intermediation and interest rates; on the long run velocities of circulation of different monetary instruments, and the use of outside money; on the patterns of saving and trade. Three phases of financial development are recognized: a cash-based economy, an economy with specialized financial markets and an economy with gross financial positions. Even if financial deepening concepts were brought into salience with the decisive work of McKinnon (1973) and Shaw (1973), these ideas can be originate in the Keynesian theories. In the Keynesian theory, financial deepening occurs due to a spreading out in government expenditure. In order to reach full employment, the public authority should introduce currency into the economy by growing government expenses. An increase in government spending increases aggregate demand and income, thereby raising demand for money.

The concept of too big to fail has not been with us forever. In fact, it only gradually entered into the economic and financial vocabulary in mid-1980's and became more frequently used in 1990's after crises, restructuration and liberalization of banking industry both in the United State and in Europe. The context of the term became apparent following a series of domestic and cross-border bank mergers, increasing popularity of economic reforms and financial innovations in the banking industry. Following the innovative changes and mutations, the rapid growth of mobile phones usage with E-banking can bridge the economic transformation and increase the bancarisation rate. Tchouassi (2012) has discussed how mobile phones can be used to extend banking services to the unbanked, poor and vulnerable population. Regression analysis was applied to identify the effects of mobile phones on bancarisation rate and, on poor and vulnerable populations. Cellular phone is statistically significant. This shows that the degree of the cellular phone consumption in an economy at any given time affect the bancarisation rate. Cellular phone is a specialized electronic financial channel using in the African countries to bank the unbanked. The cellular phone presents a great opportunity for the provision of financial services to the unbanked.

Tchouassi and Tamchap (2013) evaluate the the link between microfinance and banking reforms and bancarisation rate in the Central African State Bank (BEAC zone). The authors used statistical analysis and econometric analysis to verify the relationship. They conclude that the application of the regulation on microfinance in the CEMAC countries leads to an increase in the bancarisation stage. The bancarisation rate would be reduced further if the postal network and even mobile phone banking (m-banking) are introduced in the calculations.

In reforming banking regulation (Senbet \& Otchere, 2006; Senbet, 2009), indeed the recent crisis provides an occasion to reorganize the regulatory schemes in a comprehensive way. What is brought home is the build-up of risk exposures not only by banks but "shadow" banks stemming from regulatory gaps and distorted incentives of decision-makers in the banking and the overall financial system. Although these issues are now getting global attention, Central African countries should also put in place the appropriate measures and methodology for its moving-forward so as to reduce both the frequency of future crises and their potential severity.

\section{Methodology: Variable Selections, Econometric Model and Data Source}

\subsection{Variable Selections}

We start by selecting variables that are commonly used in bancarisation equations. These variables include financial, physical and human capital components in one hand, and institutional, regulation components in the other hand. The dependent variable is bancarisation rate. Bancarisation rate is the penetration of banking services in a population. Banked population estimated to $20 \%$ means that $80 \%$ of this population has not (yet) access to 
financial and banking services, either of its own making (refusal) or because of its financial situation is not attractive for banking. The banking penetration rate in Sub-Saharan Africa countries has hovered around $4 \%-10 \%$ over the last two decades. Within countries in the region, levels of banking climb sharply with income and education, with over $40 \%$ of people with tertiary education who have bank accounts, while only just over $3 \%$ of those with primary or no education do. There are a number of channels through which economic and financial reforms may impact bancarisation rate. These channels may be assimilating to the following explicative variables: Gross Domestic Product (GDP) per capita, Inflation, Infrastructure, Literacy rate, Institution and Financial Liberalization.

GDP per capita: GDP per capita is an approximation of the value of good produced per person in the country, equal to the country's GDP divided by the total number of people in the country. Up until now, all measures used above were normalized to the level of nominal GDP and showing how much excess growth financial institutions absorbed over certain time. However, it is difficult to assess if this is too much or too little when no benchmark is available. Economic research in financial deepening is suggesting that financial depth has macroeconomic consequences. For instance, Khan et al. (2001) finds links of financial deepening and inflation, and as discussed earlier, Klein and Olivei (1999) find positive effects of financial depth for economic growth.

INFLATION: It is a variation rate of the consumer Price Index. Inflation is a rise in consumer prices, increasing the cost of living. The inflation rate is one of the most important economic forces consistently weighing on the value of a nation's currency. The variable inflation is measured as the rate of change of the deflator of the GDP. Inflation is synonymous of economic instability. It distorts information to economic agents and discourages financial intermediation. In this paper inflation captures the macroeconomic stability of the region.

INFRASTRUCTURE: Infrastructure is a set of interconnected structural elements that provide the framework for supporting the entire development of the structure. Economic infrastructures are internal facilities of a country that make business activity possible, such as communication, transportation, distribution networks, financial institutions, markets and energy supply systems. The variable 'infrastructure' represents in this paper a proportion of telephonic subscribers and consumers. This proportion is supposed to use mobile phone banking to extend banking services.

INSTITUTION: Rule of the law is an indicator of governance constructed by the World Bank. It includes many indicators measuring confidence and the respect of the rule and the law in the society. Its value varies between -2.5 and 2.5. An increasing in the value of this indicator shows a favorable institutional environment, respectively. This variable is very important in the bancarisation analysis in the CEMAC zone.

LITERACY RATE: It is one of the components of human capital (Becker, 1964). Romer (1990) refers to the human capital as a fundamental source of economic productivity. The literacy rate is the percentage of people with the ability to read and to write. In this paper, the literacy rate represents the proportion of the adult populations aged 15 years and over that is literate.

FINANCIAL LIBERALIZATION: Financial liberalization usually involves the domestic banking sector (McKinnon, 1973; Shaw, 1973; Henry, 2003), stock market, and national capital account. Financial liberalization refers to reduction of any sort of regulations on the financial industry of a given country. The financial liberalization index is an indicator elaborated by the International Monetary Fund to evaluate financial deregulation. It is an aggregation of seven indicators taking the value 0 (for regulated), 1,2 et 3 (for deregulated) which represented: credit control, control of the interest rate, barriers at the entry, banking supervision, privatization, change control and regulation of the financial market. The economic and financial reforms have gone beyond the interest rate liberalization that has been recommended in 1980s and 1990s by the Washington Consensus. To varying degrees, African governments also have allowed the use of foreign currency instruments and opened up capital accounts. Domestic markets are developed in central bank and government debt, and international markets are expanded in government and private bonds. Capital markets are developed, but less rapidly, and are most successful in the larger, already rapidly growing. Financial liberalization covers two major types of economic policies: increasing the openness of the financial system and relaxing government control on banks.

\subsection{Econometric Model}

From Hartsenko (2004) and Tchouassi (2012), applying regression approach to show the effects of individual characteristics of populations, mobile phone is a specific innovative electronic financial instrument for unbanking. From the review of the previous literature, a new modified model is adopted. The econometric model has the following form:

$$
\mathrm{Tb}_{\text {it }}=\mu_{\mathrm{i}}+\alpha \mathrm{R}_{\mathrm{it}}+\beta \mathrm{X}_{\mathrm{it}}+\mathrm{e}_{\mathrm{it}}
$$


Where, $T b$ is the bancarisation rate, representing the matrix of the dependent variable. $R_{i t}$ is the matrix of economic reforms intended to capture the country $i$ at time $t$ and $X_{i t}$ is the matrix of explanatory variables of country $i$ at time $t$. Countries with basic infrastructure (transport, communication, energy, among others), cleared and cleaned legal and contractual framework, competitive and transparent banking sector and a dominance of state-owned banks have fewer barriers to access to financial and banking services. $e_{i t}$ is the error or residual explanation for country $i$ at time $t$ and $\mu_{i}$ is an individual consistency designed to capture the country effect. $\alpha$ and $\beta$ are parameter to be estimate. The model to be estimate is:

$$
\begin{aligned}
\text { Bancarisation rate }_{i t}= & \beta_{0}+\beta_{1} \text { GDPPc }_{i t}+\beta_{2} \text { INFLATION }_{i t}+\beta_{3} \text { INFRASTRUTURE }_{i t}+\beta_{4} \text { INSTITUTION }_{i t}+ \\
& \beta_{5} \text { LITERACYRATE }_{i t}+\beta_{6} \text { FINANCIALLIBERALIZATION }_{i t}+e_{i t}
\end{aligned}
$$

Where: Bancarisation rate is the dependent variable, GDPpc, INFLATION, INFRASTRUTURE, INSTITUTION, LITERACYRATE and FINANCIALLIBERALIZATION are independent variables. $\beta_{0}$ is the constant term. $\beta_{1}, \beta_{2}, \beta_{3}$, $\beta_{4}, \beta_{5}$ and $\beta_{6}$ are coefficients to be estimate.

The generalized method of moments (GMM) is used to estimating parameters of the empirical model. Generalized method of moments was introduced by Pearson (1894) but developed by Hansen (1982) as a generalization of the method of moments. Generalized method of moments refers to a class of estimators which are constructed from exploiting the sample moment counterparts of population moment conditions (some-times known as orthogonality conditions) of the data generating model. GMM estimators have become widely used, for the following reasons: GMM estimators have large sample properties that are easy to characterize in ways that facilitate comparison. In practice, researchers find it useful that GMM estimators can be constructed without specifying the full data generating process, which would be required to write down the maximum likelihood estimator (Hansen, 2007). This is why this method is used in this paper.

\subsection{Data Sources}

Data are from the African statistical yearbook of the African Development Bank (AfDB, 2013) and the international financial statistics of the International Monetary Fund for the period 2001-2011. Cameroon, Chad, Central African Republic, Congo Republic, Equatorial Guinea, Gabon are six countries of the CEMAC region.

\section{Empirical Results and Discussions}

Using generalized method of moment (GMM) estimators, the empirical results are presented in the Table 2 below.

\begin{tabular}{|c|c|c|c|c|c|c|c|}
\hline \multicolumn{8}{|c|}{$\begin{array}{l}\text { GMM, Generalized Moment Method } \\
\text { Group variable: country } \\
\text { Time variable: annual }\end{array}$} \\
\hline Variables & Coef & Std Err & $\mathrm{z}$ & $\mathrm{P}>|\mathrm{z}|$ & \multicolumn{2}{|c|}{ [95\% Conf. Interval] } & GMM \\
\hline BANKRATE & .0824716 & .1138302 & 0.72 & 0.469 & -.1406314 & .3055746 & $\begin{array}{c}0.082 \\
(0.113)\end{array}$ \\
\hline GDP per capita & .0289449 & .213649 & 0.14 & 0.892 & -.3897994 & .4476892 & $\begin{array}{c}0.028 \\
(0.214)\end{array}$ \\
\hline INFLATION & -.3425112 & .0976714 & -3.51 & 0.000 & -.5339436 & -.1510788 & $\begin{array}{c}-.343 * * * \\
(0.098)\end{array}$ \\
\hline INFRASTRUC & 12.30438 & 5.337481 & 2.31 & 0.021 & 1.843109 & 22.76565 & $\begin{array}{c}12.304 * * \\
(5.337)\end{array}$ \\
\hline LITERRATE & .3666988 & .1612498 & 2.27 & 0.023 & .0506549 & .6827426 & $\begin{array}{c}0.367 * * \\
(0.161)\end{array}$ \\
\hline INSTITUTION & 2.647848 & 7.25124 & 0.37 & 0.715 & -11.56432 & 16.86002 & $\begin{array}{c}2.648 \\
(7.251)\end{array}$ \\
\hline FINLIBE & .2250393 & .084727 & 2.66 & 0.008 & .0589775 & .391101 & $\begin{array}{c}0.225^{* * *} \\
(0.084)\end{array}$ \\
\hline CCONS & -18.28407 & 18.10967 & -1.01 & 0.313 & -53.77837 & 17.21023 & $=\mathrm{CONS}$ \\
\hline $\begin{array}{l}\text { Wald chi } 2(7)=44.27 \\
\text { Prob }>\text { chi } 2=0.0000 \\
\text { P-value }=0.00\end{array}$ & & & & & & & \\
\hline
\end{tabular}

Table 2. Results of the estimation

Note. Standard errors are in parentheses. $* * *=\mathrm{p}<0.01 ; * *=\mathrm{p}<0.05 ; *=\mathrm{p}<0.1$.

Source: Author's calculation. 
From Table 2, the coefficient (.225) associated with financial liberalization is positive and significant. This show banking reforms in the 1990s have contributed to banking populations in the CEMAC countries. In other words, financial liberalization has facilitated the opening of bank accounts (checking accounts and savings accounts) by the populations in the countries of the Central African Economic and Monetary Community.

GDP per capita has a coefficient (.028) positive and significant. This means that the opening of bank accounts demand is an increasing function of GDP per capita. More per capita GDP increases more people tend to access to financial and banking services. The coefficient associated to the literacy rate is equal to .366 . This means that the literacy rate contributes to the improvement of financial and banking services. More male and female populations are educated and trained, the better they trust the financial and banking system, and the self-exclusion rate is dropped.

The coefficient related to infrastructure is positive. This can be explaining by the fact that public and private infrastructures, including telecommunications, promote decentralization and delocalization of the banking network to smaller cities and rural areas in Central African countries. Increase in expenditures in innovative electronic communications infrastructures thus making them the offer of financial and banking services available in real time. Macroeconomic stability captured by the inflation rate has a positive and significant effect on the bancarisation rate of the CEMAC countries. Low and stable inflation indicates healthy demand in financial and banking services, and the marketplace. However, high or unstable inflation threaten growth. High inflation alters the value of long term contracts. Volatile inflation creates uncertainty in the market place, increasing risk premiums. Since many tax rates are adjusted by average inflation, volatile inflation can severely alter government revenues and individual liabilities.

Institutional reforms positively influence bancarisation rate. The associated coefficient is equal to 2.647. To ameliorate the unbanked rate in CEMAC region, rules and laws need to be change or readapted. National, regional regulation need to be revised and reformed according to international financial and banking regulation. Institutional reforms work best for banking the unbanking in settings where financial and banking activities are weak. This is in line with Iyigun \& Rodrik (2004) works related on the efficacy of the reforms.

\section{Conclusions and Recommendations}

Financial and banking services industries have undergone many changes and transformation in the past two decades due to deregulation, technological advances and globalization. We argued in this paper that economic reforms spur bancarisation rate in the CEMAC region. High level of innovative infrastructures, high levels of literacy among the populations, efficacy in the economic and financial reforms processes, and high rate of economic growth can accelerated the penetration of financial and banking services in the CEMAC geographical areas. True these channels, the bancarisation rate should increase in the six countries of the region.

What economic policies recommendation can be implemented to institute well performance and comprehensive monetary, financial and banking zone for growth? First, deal with regulatory bottlenecks by putting in place and enforcing rules and laws intended at developing trust in investors and banks through the construction of credit bureaus that supervise repayment proceedings. Second, restructure the monetary, financial and banking system through opening the CEMAC zone to competition, reviewing prudential ratios and putting in place innovative savings and borrowing instruments modified to limited request.

Third, increase assets markets and particularly bond markets for long term financing requests by setting up sufficient agreement schemes against money and other categories of risks. And last, channel the break between the unofficial and official monetary and financial sectors by formalizing microfinance institutions to help them scale up activities while developing financial products geared towards small and medium enterprises. Innovative financial instruments that use technology such as mobile banking can also help leapfrog traditional finance services and reach a larger population for the amelioration of the bancarisation rate.

\section{References}

African Development Bank. (2013). African Statistical Yearbook 2013. AfDB, Tunis. Retrieved from http://www.afdb.org

Becker, G. (1964). Human Capital: A theoretical and empirical analysis with special reference to education. Columbia University Press.

Bekaert, G. (1995). Market integration and investment barriers in emerging equity markets. World Bank Economic Review, 9, 75-107. http://dx.doi.org/10.1093/wber/9.1.75

Bekaert, G., \& Harvey, C. R. (1995). Time-varying world market integration. Journal of Finance, 50, 403-444. 
http://dx.doi.org/10.1111/j.1540-6261.1995.tb04790.x

Buckberg, E. (1995). Emerging stock markets and international asset pricing. World Bank Economic Review, 9 , 51-74. http://dx.doi.org/10.1093/wber/9.1.51

Buffie, E. F. (1984). Financial Repression. The New Structuralist and Stabilization Policy in Semi-Industrialized Economies. Journal of Development Economies, 14(3). http://dx.doi.org/10.1016/0304-3878(84)90061-0

Demirgüç-Kunt, A., \& Detragiache, E. (1998). The determinants of banking crises in developing and developed countries. IMF Staff Papers, 45(1), 81-109. http://dx.doi.org/10.2307/3867330

Eboué, C. (1990). Les effets macroéconomiques de la répression financière dans les pays en développement. Economie Appliquée, LXIII(4), 93-117.

Errunza, V., Losq E., \& Padmanabhan, P. (1992). Tests of integration, mild segmentation, and segmentation $\begin{array}{lllll}\text { hypotheses. Journal of Banking and } & \text { Finance, } & \text { 16, }\end{array}$ http://dx.doi.org/10.1016/0378-4266(92)90034-W

Fry, M. J. (1995). Money, Interest and Banking in Economic Development. Baltimore: Johns Hopkins University Press.

Galbis, V. (1977). Financial Intermediation and Economic Growth in Less- Developed Countries: A Theoretical Approach. Journal of Development Studies, 13(2), 58-72. http://dx.doi.org/10.1080/00220387708421622

Gurley, J., \& Shaw, E. (1960). Money in theory of finance. Washington D C, The Brookings Institution

Hansen, L. P. (1982). Large Sample Properties of Generalized Method of Moments Estimators. Econometrica, 50(4), 1029-1054. http://dx.doi.org/10.2307/1912775

Hansen, L. P. (2007). Generalized Method of Moments Estimation. Department of Economics, University of Chicago, pp. 1-14.

Henry, P. (2000). Stock Market Liberalization, Economic Reform and Emerging Market Equity Prices. The Journal of Finance, 55, 529-564. http://dx.doi.org/10.1111/0022-1082.00219

Henry, P. B. (2003). Capital-account liberalization, the cost of capital, and economic growth. American Economic Review, 93(2), 91-96. http://dx.doi.org/10.1257/000282803321946868

IMF. (2014). International Financial Statistics CD-ROM. IMF, May.

Iyigun, M., \& Rodrik, D. (2004). On the Efficacy of Reforms: Policy Tinkering, Institutional Change, and Entrepreneurship. CEPR Discussion Papers, 4399.

Kaminsky, G. L., \& Chmukler, S. L. (2003). Short-run pain, long-run gain: The effects of financial liberalization. IMF Working Paper, 03/34. Washington, D C.

Kapur, B. K. (1976). Alternative stabilization policies for less-developed economies. Journal of Political Economy, 51, 68-99. http://dx.doi.org/10.1086/260476

Khan, M. S., Senhadji, A. S., \& Smith, B. D. (2001). Inflation and financial depth. IMF Working paper, $\mathrm{WP} / 01 / 44$.

King, R. G., \& Levine, R. (1993). Finance and Growth. Journal of Economics, 108, 717-737.

Kiyotaki, N., \& Moore, J. (2004). Inside Money and Liquidity. Working Paper, London School of Economics, Revision of the Marschak Lecture delivered at the South Asia Meeting of the Econometric Society, Lahore

Klein, M., \& Olivei, G. (1999). Capital Account Liberalization, Financial Depth, and Economic Growth. NBER Working Paper, 7384.

Levine, R. (2005). Finance and Growth: Theory and Evidence, In P. Aghion, \& S. Durlauf (Eds.), Handbook of economic growth (Chapter 12). New York: Elsevier.

Mathieson, D. J. (1980). Financial Reform and Stabilization Policy in a Developing Economy. Journal of Development Economics, 7, 359-395. http://dx.doi.org/10.1016/0304-3878(80)90017-6

McKinnon, R. I. (1973). Money and Capital in Economic Development. Washington, D C: Brookings Institution

Patrick, H. T. (1966). Financial Development and Economic Growth in Underdeveloped Countries. Economic Development and Cultural Change, 14, 174-189. http://dx.doi.org/10.1086/450153

Pearson, K. (1894). Contribution to the mathematical theory of evolution. Philosophical Transactions of the Royal Society of London, 185, 71-110. http://dx.doi.org/10.1098/rsta.1894.0003 
Romer, P. M. (1990). Endogenous Technological Change. Journal of Political Economy, 98(5), 71-102. http://dx.doi.org/10.1086/261725

Sachs, J., \& Warner, A. (1995). Economic reform and the process of global integration. Brookings Papers on Economic Activity, 1, 1-113. http://dx.doi.org/10.2307/2534573

Schumpeter, J. (1912). The Theory of Economic Development. Leipzig: Dunker \& Humblot, 1912; translated by R. Opie, Cambridge, MA: Harvard U. Press.

Senbet, L. W. (2009). Financial Sector Policy Reforms in the Post-Financial Crisis Era: Africa Focus. African Development Bank Group, Working Paper, 100.

Senbet, L. W., \& Otchere, I. (2006). Financial Sector reforms in Africa: Perspectives on Issues and Policies. In F. Bourguignon, \& B. Pleskovic (Eds.), Growth and integration. Annual World Bank Conference on Development Economics.

Shaw, E. (1973). Financial Deepening in Economic Development. New York: Oxford University Press.

Stiglitz, J. E. (2000). Capital Market Liberalization, Economic Growth and Instability. World Development, 28(6), 1075-1086. http://dx.doi.org/10.1016/S0305-750X(00)00006-1

Taylor, L. (1983). Structuralist Macroeconomics: Applicable Models for the Third World. New York: Basic Books.

Tchouassi, G. (2012). Can mobile phones really work to extend banking services to the unbanked? Empirical lessons from selected Sub-Saharan Africa countries. International Journal of Developing Societies, 1(2), $70-81$.

Tchouassi, G., \& Tamchap, S. F. (2013). Influence des réformes bancaires et microfinancières sur le taux de bancarisation dans la zone BEAC. Communication aux Vèmes Journées Internationales de la Microfinance, Douala, 11, 12 et 13 Septembre 2013.

Van Wijnbergen, S. (1983). Credit Policy, Inflation and Growth in a Financial Repressed Economy. Journal of Development Economics, 13(1), 45-65. http://dx.doi.org/10.1016/0304-3878(83)90049-4

\section{Copyrights}

Copyright for this article is retained by the author(s), with first publication rights granted to the journal.

This is an open-access article distributed under the terms and conditions of the Creative Commons Attribution license (http://creativecommons.org/licenses/by/3.0/). 